\title{
Recent Developments in Multi-nutrient Extractants Used in Soil Analysis
}

\author{
Chiranjeev Kumawat ${ }^{1}$, Brijesh Yadav $^{1}$, A.K. Verma ${ }^{1}$, R.K. Meena ${ }^{1}$, \\ Ravina Pawar ${ }^{2}$, Sushil Kumar Kharia ${ }^{1}$, R.K. Yadav ${ }^{1}$, Rohitash Bajiya ${ }^{1}$, \\ Atul Pawar ${ }^{1}$, B.H. Sunil ${ }^{1}$ and Vivek Trivedi ${ }^{1}$ \\ ${ }^{1}$ ICAR-Indian Agricultural Research Institute, New Delhi-110012, India \\ ${ }^{2}$ Dr. Yashwant Singh Parmar University of Horticulture and Forestry, Solan, \\ Himachal Pradesh-173230, India \\ *Corresponding author:
}

\section{A B S T R A C T}

Keywords

Extractant, Shaking time, Extraction efficiency, DTPA

Article Info

Accepted:

25 April 2017

Available Online:

10 May 2017
Universal extractant is a term used to designate reagents or procedures to extract several elements or ions to assess soil fertility status or levels of toxicity. The extraction procedure should be rapid, reproducible, inexpensive, adaptable to soils from different regions, and extract the labile forms of nutrients which might be potentially available to plants. Most of the extractants in use are fall short of these requirements. Modified M3 method for simultaneous extraction of macro and micro nutrients in arable land soils and it was found to be greatly correlated with the existing methods for NO3-N, available $\mathrm{P}, \mathrm{Zn}, \mathrm{Cu}$ and $\mathrm{B}$, exchangeable $\mathrm{K}, \mathrm{Ca}$ and $\mathrm{Mg}$ and easily reducible $\mathrm{Mn}$. A new, easily applicable soil extraction method has been developed using the coffee percolator principle and the results are in close correlation with those of conventional soil testing methods and with the nutrient uptake of the sunflower and ryegrass used as test crops. Several techniques using cation or anion exchange resins which allow the simultaneous extraction of $\mathrm{Ca}, \mathrm{Mg}, \mathrm{K}, \mathrm{Al}$, $\mathrm{Mn}$ and $\mathrm{P}$ from soil were assessed and all the resin procedures have the potential to reduce the time required for analysis of $\mathrm{Ca}, \mathrm{Mg}, \mathrm{K}, \mathrm{Mn}$ and $\mathrm{P}$ in soil. Despite of these developments, today the challenge is to select an appropriate extractant that take full advantage of multi-element analysers such as the ICP, suitable for a range of soil characteristics, such as $\mathrm{pH}$, texture, organic matter content, and having an established significant relationship between elemental level and crop response. Therefore evaluation of various extraction methods for use under particular soil conditions, in various regions or within specific cropping situations is still needed.

\section{Introduction}

From 1960s to 2016, from subsistence farming to sustainable farming, from deficiency in food grain production to sufficiency in food grain production, there has been a continuous increase in fertilizer use in India and side by side there is an increase in different nutrient deficiency occurring in soil. In Marusthali $12 \%$ soils are deficient in
NPKSZn, similarly $18 \%, 35 \%, 36 \%$ soils of Chhotnagpur plateau, Bengal basin and Rajasthan Bagar areas are deficient in NPKSBZn, NKB and NK respectively. So in order to get this multinutrient deficiency or sufficiency status of the soil rapidly and accurately, a multinutrient extractant is necessary. There has been continuous 
research and development going on in this aspect for years but till date no perfect multinutrient extractant has been developed although many researchers have found remarkable results. Universal extractant is a term used to designate reagents or procedures to extract several elements or ions to assess soil fertility status or levels of toxicity. Universal soil extractants ideally should be: (i) adequate for the simultaneous determination of all plant nutrients; (ii) rapid; (iii) reproducible; (iv) inexpensive; (v) adaptable to all types of soils; (vi) and, overall, the best possible alternative for the evaluation of the plant available amount of the nutrient. The advantage of extracting several elements with a single solution has always been attractive for the routine laboratory work, moreover using modern equipment which allows simultaneous determination of several elements, as the inductively coupled argon plasma emission spectrometer (Raij, 1994; Jones, 1998).

\section{Materials and Methods}

\section{Morgan's reagent}

The first universal soil extracting reagent was developed by Morgan, a $0.73 \mathrm{M}$ sodium acetate $\left(\mathrm{NaC}_{2} \mathrm{H}_{3} \mathrm{O}_{2}\right)$ solution buffered at $\mathrm{pH}$ 4.8. The shaking time was 15 minutes and Soil: solution is 1:4. In 1941, the Morgan extractant procedure was described in the Connecticut Experiment Station Bulletin 450 which was followed by Bulletin 541 in 1950 . These bulletins described in some detail the analysis procedures and interpretative data for the determination of 15 elements and ions. The Morgan extraction reagent was widely used in the 1950s and early 1960s, but it is in little use today. The parameters determined by this reagent are $\mathrm{P}, \mathrm{K}, \mathrm{Ca}, \mathrm{Mg}, \mathrm{Cu}, \mathrm{Fe}, \mathrm{Mn}, \mathrm{Zn}$, $\mathrm{NO}_{3}, \mathrm{NH}_{4}, \mathrm{SO}_{4}, \mathrm{Al}, \mathrm{As}, \mathrm{Hg}, \mathrm{Pb}$. The $\mathrm{pH}$ of 4.8 was chosen to simulate the carbon dioxide saturated solution adjacent to the root hairs.
This $\mathrm{pH}$ would act as a mild solvent for iron and aluminium phosphates as well as other minerals that might release ions important in plant nutrition. The sodium acetate would be effective in replacing important soil cations and anions into the extract solution so that they could be readily measured.

The use of sodium acetate and acetic acid permitted the determination of all important soil nutrients with exception of sodium in a single extract (Morgan, 1941).

\section{Wolf reagent (Modified Morgan’s reagent)}

Wolf modified Morgan's reagent in 1982 (Wolf, 1982). The Morgan-Wolf Extraction Reagent is for use with acid to neutral $\mathrm{pH}$ soils irrespective of texture as the soil aliquot measurement is by volume. The extraction reagent is a mixture of $0.073 \mathrm{M}$ sodium acetate $\left(\mathrm{NaC}_{2} \mathrm{H}_{3} \mathrm{O}_{2}\right), \quad 0.52 \mathrm{~N}$ acetic acid $\left(\mathrm{CH}_{3} \mathrm{COOH}\right)$ and $0.001 \mathrm{M}$ diethylenetriarnine pentaacetic acid (DTPA) buffered at $\mathrm{pH} 4.8$. The extraction reagent is best suited for the assay of well fertilized soils and most effective for monitoring their fertility level.

\section{Mehlich no. 1 (M 1) reagent}

In 1954, the Mehlich No. 1 (frequently referred to in the past as either the North Carolina or Double Acid) extraction reagent was introduced, an extractant that is still in wide use today for the determination of $\mathrm{P}, \mathrm{K}$, $\mathrm{Ca}, \mathrm{Mg}, \mathrm{Na}, \mathrm{Mn}$ and $\mathrm{Zn}$ in acid sandy soils primarily from the eastern and south-eastern coastal areas of the United States.

The extraction reagent is a mixture of $0.05 \mathrm{~N}$ $\mathrm{HC} 1$ in $0.025 \mathrm{~N} \mathrm{H}_{2} \mathrm{SO}_{4}$. The Soil:solution is 1:4 and Shaking time $5 \mathrm{~min}$. The acid has been used here to extract elements from acid soluble fraction as well as it extracts from water soluble and exchangeable fraction from soil. 


\section{Mehlich no. 2 (M 2) reagent}

Mehlich modified M 1 reagent in 1978 to allow simultaneous extraction of several plant nutrients over a wide range of soil properties. The new extractant is composed of $0.2 \mathrm{~N}$ $\mathrm{NH}_{4} \mathrm{Cl}-\mathrm{O} .2 \mathrm{~N} \quad \mathrm{HOAc}-0.015 \mathrm{~N} \quad \mathrm{NH}_{4} \mathrm{~F}-0.012 \mathrm{~N}$ $\mathrm{HCl}$ at approximately $\mathrm{pH} 2.5$. The double acid (DA) extractant $\left(0.05 \mathrm{~N} \mathrm{HC} 1-0.025 \mathrm{~N} \mathrm{H}_{2} \mathrm{SO}_{4}\right)$ meets many of the requirements of a mass analyses method for $\mathrm{P}, \mathrm{K}, \mathrm{Ca}, \mathrm{Mg}, \mathrm{Na}, \mathrm{Mn}$ and $\mathrm{Zn}$. However, DA is not recommended for calcareous soils or on acid soils containing recently applied rock phosphate. Under these conditions, DA extracts $\mathrm{P}$ in considerable excess of that obtained with Bray 1 and Olsen. In acid soils in the absence of phosphate rock improved extraction efficiency and correlation with Bray 1 were obtained by increasing the soil: extractant ratio of the DA method from 1:5 to 1:10 and by adding HF or NH4F to the reagent. With calcareous soils Smith, Ellis and Grava (1957) found that Bray 1 gave a high correlation between percentage yield of wheat and extractable $\mathrm{P}$ at a 1:50 soil: extractant ratio. Randall and Grava (1971) also obtained a significant decreasing curvilinear relationship between quantities of calcitic carbonates of calcareous soils and Bray 1 extractable $\mathrm{P}$ at 1:10, 1:50 and 1:100 soil: solution ratios. The depressing effect of $\mathrm{CaCO}_{3}$, was considered due to neutralization of $0.025 \mathrm{~N} \mathrm{HC} 1$ and the deactivation of $\mathrm{F}$ ion in $0.03 \mathrm{~N} \mathrm{NH} \mathrm{NH}_{4} \mathrm{~F}$ by the formation of insoluble calcium fluoride. Smillie and Syers subsequently confirmed formation of $\mathrm{CaF}_{2}$ during a 1 minute extraction of calcite with Bray 1 and simultaneous sorption of added P. Recent observations by Mehlich showed that precipitation of $\mathrm{CaF}_{2}$ was not restricted to calcareous soils, but may occur in neutral and acid soils. It was also shown that the advantages of the fluoride ion, when added to $0.025 \mathrm{~N} \mathrm{HC} 1$ to control selective extractability of $\mathrm{P}$, did not apply simultaneously to $\mathrm{Ca}$ unless the $\mathrm{pH}$ of the extractant was held below about $\mathrm{pH}$ 2.9. To achieve this objective in calcareous soils either a wide soil: extractant ratio or a considerable higher buffer capacity is required than is inherent in Bray 1. An extractant having the composition $0.2 \mathrm{~N} \quad \mathrm{NH}_{4} \mathrm{C} 1-0.2 \mathrm{~N} \quad \mathrm{HOAc}-0.015 \mathrm{~N} \quad \mathrm{NH}_{4} \mathrm{~F}-$ $0.012 \mathrm{~N} \mathrm{HC1}$ at approximately $\mathrm{pH} 2.5$, was reported by Mehlich to offer the desirable buffer properties for the simultaneous extraction of $\mathrm{P}$ and $\mathrm{Ca}$ from rock phosphate and soils (Mehlich, 1978, 1984).

\section{Mehlich no. 3 (M 3) reagent}

Mehlich 2 reagent was modified to include $\mathrm{Cu}$ among the extractable nutrients, retain or enhance the wide range of soils for which it is suitable and minimize its corrosive properties. The substitution of nitrate for chloride anions and the addition of EDTA accomplished those objectives. The new extracting solution, already designated Mehlich 3 (M3) is composed of $0.2 \mathrm{~N} \quad \mathrm{CH}_{3} \mathrm{COOH}-0.25 \mathrm{~N}$ $\mathrm{NH}_{4} \mathrm{NO}_{3}-0.015 \mathrm{~N} \mathrm{NH} \mathrm{N}_{4} \mathrm{~F}-0.013 \mathrm{~N} \mathrm{HNO}_{3}-$ $0.001 \mathrm{M}$ EDTA pH buffered at $2.5 \pm 0.1$.

Mylavarupu and co-workers in 2002 have been found that mean extracted concentration of $\mathrm{K}, \mathrm{Mg}$, and $\mathrm{Zn}$ was not significantly different between $\mathrm{M}-1$ and $\mathrm{M}-3$ procedures for all the samples ( $L S D, p=0: 05$ ). The range, standard deviation and interquartile dispersion of concentrations were also found to be very similar for $\mathrm{K}, \mathrm{Mg}$, and $\mathrm{Zn}$ for both the procedures. The extractable mean concentrations of M-3-P, M-3-Cu, M-3-Mn, and M-3-B were significantly higher compared to the corresponding M-1 extractable amounts. M-1-Ca was however found to be significantly higher than M-3-Ca. Since the M-3 solution contained dilute acids and EDTA, M-3 procedure was expected to extract larger amounts of micronutrients. The higher amounts of $\mathrm{Mn}, \mathrm{Zn}$, and $\mathrm{Cu}$ extracted by M3 could be attributed to the addition of 
EDTA that resulted in solubilizing oxidized and organic forms of those nutrients. Mehlich found that addition of EDTA to the M-3 solution increased the $\mathrm{Cu}, \mathrm{Mn}$, and $\mathrm{Zn}$ by $170 \%, 50 \%$, and $25 \%$ compared to the extracting solution without EDTA addition.

However, there was a statistical difference in the slope of the regression line between the soils having $\mathrm{pH} 4.30-7.30$ and $\mathrm{CaCO}_{3} \quad 0-0.9$ percent and the two other groups of soils $(\mathrm{pH}$ 7.01-8.17 and $\mathrm{CaCO}_{3}$ 1-9.5 percent; $\mathrm{pH}$ 7.20-8.28 and $\mathrm{CaCO}_{3}$ 10-48.3 percent). However, Mehlich 3 has proven to be an efficient and versatile extractant for soils containing calcium carbonates, due to the combination of acetic and nitric acids used in this solution that have a dissolving action against $\mathrm{CaCO}_{3}$ (Sawyer and Mallarino, 1999).

Wang et al., in 2004 found that the P ratios of the two methods are around 1 for most soils that have $\mathrm{pH}<6.5$. According to Smillie and Syers (1972), acidity less than $0.1 \mathrm{M} \mathrm{HCl}$ in Bray extractant would be insufficient to prevent $\mathrm{P}$ immobilization by $\mathrm{CaF}_{2}$ formed during $\mathrm{NH}_{4} \mathrm{~F}-\mathrm{HCl}$ extraction of calcareous soils. Mehlich also pointed out that the strength of extractant acidity, not fluoride, has a greater effect on $\mathrm{P}$ extraction in calcareous soils. These results further confirm the difference between these two extractants in $\mathrm{P}$ extraction in acid or calcareous soil environments. The results suggest that different conversion equations may need to be established based on soil $\mathrm{pH}$. On the other hand, Bray 2 with stronger acidity appears to be able to overcome the problem associated with $\mathrm{P}$ extractability loss by Mehlich series and Bray 1 extractants (Wang et al., 2004).

\section{Modified Mehlich no. 3 reagent}

Yanai et al.,in 2000 modified Mehlich 3 extractant for simultaneous extraction of macro- and micro-nutrients in arable land soil.
Composition and concentration of the new multinutrient extractant were $0.2 \mathrm{M}$ $\mathrm{CH}_{3} \mathrm{COOH}, 0.25 \mathrm{M} \mathrm{NH}_{4} \mathrm{Cl}, 0.005 \mathrm{M} \mathrm{C} 6 \mathrm{H} 807$ (citric acid), $0.05 \mathrm{M} \mathrm{HCI}$ and $\mathrm{pH}$ is to be maintained at 1.3. The extraction method consisted of continuous shaking for $30 \mathrm{~min}$ with a ratio of air-dried soil to extractant 1: 10 $(w / v)$. Advantages of the new extractant over M-3 extractant are $\mathrm{NO}_{3}-\mathrm{N}$ cannot be evaluated with the extractant, $0.005 \mathrm{M}$ citric acid used to omit the $\mathrm{F}$ ions in the extractant because fluoride ions in the Mehlich 3 extractant may dissolve $\mathrm{K}$ from the glass bottles and EDTA in Mehlich 3 precipitates after prolonged storage so $\mathrm{pH}$ is decreased by $\mathrm{HCl}$ in the new extractant.

\section{AB-DTPA method}

A new soil test was developed for simultaneous extraction of $\mathrm{NO}_{3}, \mathrm{P}, \mathrm{K}, \mathrm{Zn}, \mathrm{Fe}$, $\mathrm{Cu}$ and $\mathrm{Mn}$ from alkaline soils. The new extraction solution is $1 \mathrm{M}$ in ammonium bicarbonate $\left(\mathrm{NH}_{4} \mathrm{HCO}_{3}\right), 0.005 \mathrm{M}$ in Diethylene Triamine Pentaacetic Acid (DTPA) and has a pH of 7.6 (Soltanpour and Schwab, 1977). The simple correlation coefficients, it is obvious that there exists a high degree of correlation between the new method and the standard methods of extraction. Since a considerable amount of calibration work for different soils and climatic conditions are available for standard methods of soil testing, the regression equations between the new and the standard methods will allow one to calculate index values of nutrients in soils for the new soil test. This was done for $\mathrm{P}, \mathrm{K}, \mathrm{Zn}, \mathrm{Fe}, \mathrm{Cu}$ and $\mathrm{Mn}$ index values used for fertilizer recommendations by the Colorado State University Soil Testing Laboratory. Trehan and Grewal (1985) experimented on different soils across various climatic regions in India to find out the suitability of AB-DTPA in Indian soils and found that for alluvial soils highest correlation was found for $\mathrm{P}$ and 
lowest for $\mathrm{Mg}$. Similarly for hilly soils highest correlation was found for $\mathrm{Ca}$ and lowest for $\mathrm{Cu}$ respectively. Pradhan et al., (2015) found out the relationship of extractable $\mathrm{Cu}$ and $\mathrm{Zn}$ with important physico-chemical properties of soil. The amount of $\mathrm{Cu}$ extracted by the 4 extractants showed a significant positive correlation with organic $\mathrm{C}$. This indicated that the extractable $\mathrm{Cu}$ content of the soils would increase with increasing organic C. DTPA-Cu showed a significant negative correlation with soil $\mathrm{pH}$ while, Mehlich 3-Cu had a significantly positive correlation with $\mathrm{pH}$.

\section{Hot Water Percolation (HWP) method}

A new, easily applicable soil extraction method i.e. the hot water percolation method (HWP) has been developed using the coffee percolator principle. During hot water percolation the available, desorbable, easily soluble elements are extracted by hot water $\left(102-105^{\circ} \mathrm{C}\right)$ at $120-150 \mathrm{kPa}$ pressure. Nearly every nutrient is extracted by this method in measurable quantities, and the macroelements in appreciable quantities. The variation coefficient (CV \%) of the method is in average $11 \%$. The results are in close correlation with those of conventional soil testing methods and with the nutrient uptake of the sunflower and ryegrass used as test plants (Fuleky and Czinkota, 1993).

In addition, there is a close correlation with the $\mathrm{K}$ uptake of ryegrass plants, and there are also correlations with the $\mathrm{K}, \mathrm{Ca}$ and $\mathrm{Cu}$ uptake of sunflower. There is no correlation between the $\mathrm{Fe}$ and $\mathrm{Zn}$ values measured by the HWP method and the Fe and Zn uptake of sunflower plants (Fuleky and Czinkota, 1993).

\section{Resin extraction method}

McLaughlin et al., in 1994 found out the relationships between elements extracted using resin-bead \& resin membrane method and conventional method which shows except for $\mathrm{Al}$, there was generally good agreement between concentrations of elements extracted by resin methods and conventional methods of soil analysis. The resin procedures extracted much less Al than the method using $1 \mathrm{M} \mathrm{KC1}$. The relationship between resinextractable $\mathrm{P}$ and Olsen-P $(\mathrm{R} 2=0.66$ for unconfined resin beads and 0.76 for resin membranes) was weaker than relationships between $\mathrm{Ca}, \mathrm{Mg}, \mathrm{K}$ and $\mathrm{Mn}$ extracted by resin and conventional procedures.

\section{Results and Discussion}

\section{H3A-1 Method}

Haney et al., in 2006 developed a new soil extractant (H3A) with the ability to extract $\mathrm{NH}_{4}, \mathrm{NO}_{3}$, and $\mathrm{P}$ from soil was developed and tested against 32 soils, which varied greatly in clay content, organic carbon (C) and soil $\mathrm{pH}$. The extractant (H3A) eliminates the need for separate phosphorus (P) extractants for acid and calcareous soils and maintains the extract $\mathrm{pH}$, on average, within one unit of the soil $\mathrm{pH}$. The extractant is composed of organic root exudates, lithium citrate, and two synthetic chelators (DTPA, EDTA).

The composition and concentration of the extractant is Lithium citrate $(0.02 \mathrm{M})$, Citric acid $(0.0024 \mathrm{M})$, Malic acid $(0.004 \mathrm{M})$, Oxalic acid $(0.004 \mathrm{M}), 0.002 \mathrm{M}$ EDTA, $0.001 \mathrm{M}$ DTPA, $\mathrm{pH}$ is to be maintained around 5.0, Soil : solution $=1: 10,30$ minutes shaking, 8 minutes centifugation $3000 \mathrm{rpm} . \mathrm{P}, \mathrm{NO}_{3}-\mathrm{N}$, $\mathrm{NH} 4-\mathrm{N}$ can be determined by this single extractant.

Advantages of this extractant is that this would extract the nutrients near soil $\mathrm{pH} \pm 1$ unit, Lithium would act somewhat like $\mathrm{K}$ for replacing $\mathrm{NH}_{4}$ from exchange sites, Organic acids made the extractant more flexible for use across a wider range of soil $\mathrm{pH}$. 


\section{H3A-2 method}

Haney et al., in 2010 modified H3A-1 to reduce the extractable iron and aluminum and improve the nutrient extracting relationships with other well-known soil extractants. Correlations show improved relationships with $\mathrm{NO}_{3}, \mathrm{NH}_{4}, \mathrm{PO}_{4}, \mathrm{P}$, potassium, calcium, and zinc when compared to the original $\mathrm{H}_{3} \mathrm{~A}$ 1 as well as standard soil-test methods [Olsen, potassium chloride $(\mathrm{KCl})$, water, Mehlich 3 , Bray 1, ammonium acetate $\left(\mathrm{NH}_{4} \mathrm{OAc}\right)$, and diethylene triaminepentaacetic acid (DTPA)]. The Composition and concentration of the multi-nutrient extractant is $2 \mathrm{~g} / \mathrm{L}$ lithium citrate $(0.02 \mathrm{M}), 0.6 \mathrm{~g} / \mathrm{L}$ citric acid $(0.0024$ M), $0.4 \mathrm{~g} / \mathrm{L}$ malic acid $(0.004 \mathrm{M}), 0.4 \mathrm{~g} / \mathrm{L}$ oxalic acid $(0.004 \mathrm{M}), \mathrm{pH}=4.4$, Soil : solution $=1: 10$, Shaking time $=5$ minutes and Centrifugation $=5$ minutes. The modified extractant (H3A-2) averaged $12 \%$ more inorganic $\mathrm{N}\left(\mathrm{NH}_{4}\right.$ and $\left.\mathrm{NO}_{3}\right)$ than the original (H3A-1) based on the 60 NAPT samples.

In conclusion Morgan wolf, Mehlich 3 and modified mehlich 3 methods can be utilized to assess nutrient status in acid soils.AB-DTPA method is the only available method for assessing nutrient status in alkaline soils. Texture and $\mathrm{CaCO}_{3}$ content should be considered while using Mehlich 3 as a multinutrientextractant. H3A-2 method may be used as a multinutrient extractant to simultaneously determine inorganic $\mathrm{N}, \mathrm{P}, \mathrm{K}$, $\mathrm{Ca}, \mathrm{Zn}$. AB-DTPA and Mehlich-3 extractant can be more useful by use of instruments like ICP-MS/OES. Field calibration data for different extraction methods are still lacking so methods should be calibrated in specific field and crop conditions (Mehlich, 1953).

\section{References}

Fuleky, Gy. and Czinkota, I. 1993. Hot water percolation (HWP): A new rapid soil extraction method. Plant and Soil, 157: 131-135.
Haney, R.L., Haney, E.B., Hossner, L.R. and Arnold, J.G. 2006. Development of a new soil extractant for simultaneous phosphorus, ammonium, and nitrate analysis. Commun. Soil Sci. Plant Anal., 37: 1511-1523.

Haney, R.L., Haney, E.B., Hossner, L.R. and Arnold, J.G. 2010. Modifications to the new soil extractant H3A-1: A Multinutrient extractant. Commun. Soil Sci. and Plant Anal., 41:1513-1523.

Jones, Jr., J.B. 1998. Soil test methods: Past, present, and future use of soil extractants. Commun. Soil Sci. Plant Anal., 21: 1091-1101.

McLaughlin, M.J., Lancaster, P.A., Sale, P.G., Uren, N.C. and Peverill, K.I. 1994. Comparison of cation/anion exchange resin methods for multielement testing of acidic soils. Aust. J. Soil Res., 32: 229-240.

Mehlich, A. 1953. Determination of $\mathrm{P}, \mathrm{Ca}$, $\mathrm{Mg}, \mathrm{K}, \mathrm{Na}$, and NH4 Mimeograph. North Carolina Soil Testing Division, Raleigh, NC.

Mehlich, A. 1978. Newextractant for soil test evaluation of phosphorus, potassium, magnesium, calcium, sodium, manganese and zinc. Commun. Soil Sci. Plant Anal., 9(6): 477-492.

Mehlich, A. 1984. Mehlich 3 soil test extractant: A modification of Mehlich 2 extractant. Commun. Soil Sci. Plant Anal., 15: 1409-1416.

Morgan, M.F. 1941. Chemical Diagnosis by the Universal Soil Testing System. Conneticut Agricultural Experiment Station (New Haven. Bulletin 450.

Mylavarapu, R.S., Sanchez, J.F., Nguyen, J.H. and Bartos, J.M. 2002. Evaluation of Mehlich-1 and Mehlich-3 extraction procedures for plant nutrients in acid mineral soils of Florida. Commun. Soil Sci. Plant Anal., 33(5\&6): 807-820.

Pradhan, A.K., Beura, K.S., Das, R., Padhan, D., Hazra, G.C., Mandal, B., De, N., 
Mishra, V.N., Polara, K.B. and Sharma, S. 2015. Evaluation of extractability of different extractants for zinc and copper in soils under long-term fertilization. Plant Soil Environ., 61(5): 227-233.

Raij, B. van. 1994. New diagnostic techniques, universal soil extractants. Commun. Soil Sci. Plant Anal., 25(7\&8): 799-816.

Randall, G. W., \& Grava, J. 1971). Effect of soil: Bray no. 1 ratios on the amount of phosphorus extracted from calcareous Minnesota soils. Soil Sci. Society of America J., 35(1), 112-114.

Sawyer, J.E., \& Mallarino, A.P. 1999. Differentiating and Understanding the Mehlich 3, Bray, and Olsen Soil Phosphorus Tests.

Smillie, G. W., \&Syers, J. K. 1972. Calcium fluoride formation during extraction of calcareous soils with fluoride: II. Implications to the Bray P-1 test. Soil Science Society of America J., 36(1), 25-30.

Smith, F. W., Ellis, B. G., \& Grava, J. 1957. Use of acid-fluoride solutions for the extraction of available phosphorus in calcareous soils and in soils to which rock phosphate has been added. Soil
Science Society of America J., 21(4), 400-404.

Soltanpour, P.N. and Schwab, A.P. 1977. A new soil test for simultaneous extraction of macro- and micro-nutrients in alkaline soils. Commun. Soil Sci. Plant Anal., 8: 195-207.

Trehan, S. P., \& Grewal, J. S. 1985). Suitability of Ammonium BicarbonateDTPA Soil Test for P, K, Ca, Mg, Zn, $\mathrm{Cu}, \mathrm{Fe}$ and $\mathrm{Mn}$ in Acidic and Alkaline Soils. J. Indian Society of Soil Science, 33(3), 721-724.

Wang, J.J., Harrell, D.L., Henderson, R.E. and Bell, P.F. 2004. Comparison of soiltest extractants for phosphorus, potassium, calcium, magnesium, sodium, zinc, copper, manganese, and iron in Louisiana soils. Commun. Soil Sci. Plant Anal., 35(1\&2): 145-160.

Wolf, B. 1982. An improved universal extracting solution and its use for diagnosing soil fertility. Commun. Soil Sci. Plant Anal., 13: 1005-1033.

Yanai, M., Uwasawa, M. and Shimizu, Y. 2000. Development of a new multinutrient extraction method for macro- and micro-nutrients in arable land soil. Soil Sci. Plant Nutr., 46(2): 299-313.

\section{How to cite this article:}

Chiranjeev Kumawat, Brijesh Yadav, A.K.Verma, R.K.Meena, Ravina Pawar, Sushil Kumar Kharia, R.K.Yadav, Rohitash Bajiya, Rohitash Bajiya1, Atul Pawar, B.H. Sunil and Vivek Trivedi. 2017. Recent Developments in Multi-nutrient Extractants Used in Soil Analysis. Int.J.Curr.Microbiol.App.Sci. 6(5): 2578-2584. doi: https://doi.org/10.20546/ijcmas.2017.605.290 